\section{Anti-inflammatory and Anti- resorptive Effects of Atorvastatin on Alveolar Bone Loss in Wistar Rats}

Paula Goes ${ }^{1}$, Neiberg Alcântara Lima², José Ariévilo Gurgel Rodrigues ${ }^{3}$, Norma Maria Barros Benevides ${ }^{3}$, Gerly Anne Castro Brito ${ }^{4}$, Vilma Lima ${ }^{2}$

\author{
'Department of Pathology and Legal \\ Medicine, UFC - Universidade Federal \\ do Ceará, Fortaleza, CE, Brazil \\ ${ }^{2}$ Department of Physiology and \\ Pharmacology, UFC - Universidade \\ Federal do Ceará, Fortaleza, CE, Brazil \\ ${ }^{3}$ Department of Biochemistry and \\ Molecular Biology, UFC - Universidade \\ Federal do Ceará, Fortaleza, CE, Brazil \\ ${ }^{4}$ Department of Morphology, \\ UFC - Universidade Federal do \\ Ceará, Fortaleza, CE, Brazil
}

Correspondence: Profa. Dra. Paula Goes, Rua Monsenhor Furtado, s/n, 60441-750 Fortaleza, CE, Brasil. Tel: +55-85-3366-8301. e-mail: paulagpinheiro@yahoo.com.br
The aim of this study was to evaluate the anti-inflammatory and anti-resorptive effect of atorvastatin (ATV) in an experimental alveolar bone loss (ABL) model. Wistar rats were subjected to ligature placement around the maxillary second molar for 11 days. The animals received $0.9 \%$ saline $(2 \mathrm{~mL} / \mathrm{kg})$ or $\operatorname{ATV}(0.3,3$ or $27 \mathrm{mg} / \mathrm{kg})$ daily by gavage. $A B L$ was evaluated by resorption area and histopathological analysis. Serum bone-specific alkaline phosphatase (BALP) activity was also evaluated. Leukogram was performed at 0 $h, 6$ th $h, 2 n d, 7$ th and 11 th days. Kidney and liver conditions and the body mass variation were analyzed. ATV (3 and $27 \mathrm{mg} / \mathrm{kg}$ ) inhibited ABL by $39 \%$ and $56 \%$, respectively. Histopathological analysis showed that ATV $27 \mathrm{mg} / \mathrm{kg}$ prevented ABL and cemental resorption, and inflammatory cell infiltration induced by ligature. ATV $(27 \mathrm{mg} / \mathrm{kg})$ prevented serum BALP levels reduction. ATV $(27 \mathrm{mg} / \mathrm{kg})$ prevented leukocytosis and did not affect either kidney or liver function nor body mass weight. ATV showed a protecting effect in the ligature-induced periodontitis, without affecting system parameters, by inhibition of inflammatory process and by its anabolic activity on the alveolar bone.
Key Words: alveolar bone loss, periodontitis, inflammation, atorvastatin.

\section{Introduction}

Periodontitis is an inflammation that extends deeply into the tissues causing loss of supporting connective tissue and alveolar bone. Periodontal disease (PD) is one of the two major dental problems, followed by caries, which affect human population at high prevalence rates (1).

PD is currently understood as a result of a complex interplay between bacterial infection and host response, modified by behavioral factors. Periodontal inflammatory process initially has a protective role against bacterial invasion. However, it becomes destructive due to a prolonged over-expression of damaging mediators such as IL-1 and TNF, and expression of other mediators, such as prostaglandins, which lead to production of lytic enzymes and stimulate osteoclast recruitment (2).

Statin or 3-hydroxy-3-methylglutaryl coenzyme A (HMG-CoA) reductase inhibitor is a well-established pharmaceutical agent that effectively lowers serum cholesterol levels. Statins have been used for hypercholesterolemia treatment and atherosclerosis (3). Some studies have also suggested that statins may have other effects beyond lipid reducing function (4). They are able to modulate inflammation by lowering cytokine concentrations and inhibiting recruitment, migration and cell adhesion to endothelium. Additionally, they have shown anabolic effect on bone tissue (5).

Moreover, in the midst of various statins, atorvastatin
(ATV) stands out not only due to its lipophilicity, which is closely linked to pleiotropic effects (4), but also due to few adverse effects and better cost-effectiveness relationship, compared with other statins, being therefore, widely used in clinical practice. Therefore, considering the pleiotropic effects of statins, this study was designed to evaluate the anti-resorptive effect of ATV over inflammatory response and bone loss in an experimental model of alveolar bone loss in rats.

\section{Material and Methods Animals}

Thirty-six male Wistarrats ( $\pm 200 \mathrm{~g}$ ) (Rattus novergicus) were used in this study. Animals were kept in cages in temperature-controlled rooms, with free access to food and water during the whole experiment. Adequate measures were taken to minimize pain or discomfort to the animals. All procedures and animal treatment were conducted after approval by the institutional Ethics Committee (Protocol number 74/07).

\section{Model of Ligature-Induced Alveolar Bone Loss}

The model of ligature-induced alveolar bone loss (ABL) used in this study has previously been described (6). Rats were anesthetized with chloral hydrate (300 mg/kg, i.p.), and a nylon (00) thread ligature (Point Suture; Point Suture of Brazil, Fortaleza, CE, Brazil) was placed around the cervix 
of the maxillary left second molar. The ligature was then knotted on the buccal side of the tooth. The contralateral right side was used as the unligated control. Rats were euthanized on the $11^{\text {th }}$ day, time of peak of alveolar bone loss (6). The ligatures were blinded to the group.

\section{Experimental Groups}

Groups of 6 animals each received $0.9 \%$ saline solution $\left(2 \mathrm{~mL} / \mathrm{kg}\right.$ ), or 0.3, 3 and $27 \mathrm{mg} / \mathrm{kg}$ ATV (Lipitor ${ }^{\circledR} ;$ Pfizer; São Paulo, SP, Brazil), respectively, administrated by gavage 30 min before ligature and daily until the $11^{\text {th }}$ day.

\section{Morphometric Analysis of Alveolar Bone}

On the $11^{\text {th }}$ day, animals were sacrificed under anesthesia and had their maxillae removed and fixed in 10\% neutral formalin for $24 \mathrm{~h}$. Following, maxillae were split in half, dissected and stained with $1 \%$ methylene blue in order to differentiate bone from teeth (6). For the measurement of $A B L$, hemi-maxillae were placed in microscope slides and photographed with a digital camera (Nikon ${ }^{\circledR}$ D40, Melville, NY, USA). The acquired image was analyzed using the IMAGE J ${ }^{\circledR}$ software (ImageJ 1.32j; National Institute of Health, Bethesda, MD, USA), according to the methodology $\vec{\sigma}$ described by Goes et al. (7-9).

\section{Histological Analysis of Alveolar Bone}

Two additional groups of 6 animals submitted to ligature-induced ABL, which received saline or ATV (27 $\mathrm{mg} / \mathrm{kg}$ ), were sacrificed as described above and had their maxillae removed. The specimens were fixed in 10\% neutral buffered formalin and demineralized in 10\% nitric acid. Following this, the specimens were dehydrated, embedded in paraffin and sectioned along the molars in a mesiodistal plane for Mallory Trichrome staining (9). Four-micrometerthick sections, corresponding to the area between the first and second molars were evaluated by light microscopy at $40 \times$ magnification. Parameters such as inflammatory cell infiltration, osteoclast number, and alveolar bone and cementum integrity, were determined using scores varying from 0 to 3 according to the intensity of findings, as follows: Score 0: absence or only discrete cellular infiltration, few osteoclasts, preserved alveolar process and cementum; Score 1: moderate cellular infiltration, presence of some osteoclasts, some but minor alveolar process resorption and intact cementum; Score 2: severe cellular infiltration, large number of osteoclasts, accentuated degradation of the alveolar process, and partial destruction of cementum; Score 3: severe cellular infiltrate, total destruction of alveolar process and cementum (6).

\section{Histomorphometric Analysis}

The slides used for histological analysis were also used for the histometric study. The slide inclusion criteria were: presence of a bone crest and furcation roof in the same section. Images of these sections were captured at $40 x$ magnification. After excluding the first and last sections, four equally distant sections of each tooth were selected for histometric analysis. An observer, blinded to the group to which the slide belonged to, used the IMAGEJ ${ }^{\circledR}$ software to obtain three area measurements between alveolar bone crest $(A B C)$ and furcation roof (FR) of the maxillary second molar. This methodology was based on the study of Goes et al. (9), with some modifications, as the area between ABCFR was determined by the mean of the 3 measurements.

\section{Serum Dosage Variation of BALP Activity}

Blood samples were collected from orbital plexus of anesthetized rats (saline and ATV $27 \mathrm{mg} / \mathrm{kg}$ ) before the experiment and on the 11 th day. BALP was evaluated by indirect method, after heating the sample to $56{ }^{\circ} \mathrm{C}$ for 10 $\min (8)$. Since BALP is a thermosensible isoform of total alkaline phosphatase (TAP), its serum levels were calculated subtracting the values of heat alkaline phosphatase (HAP) from the ones of TAP. Methodology used followed the manufacturer's instructions (Labtest ${ }^{\circledR}$; Lagoa Santa, MG, Brazil).

\section{Hematologic Study}

The method used for white blood cell count was as follows: $20 \mu \mathrm{L}$ of blood, taken from the rat's tail, was added to $380 \mu \mathrm{L}$ Turk solution. Total and differential white blood cell counts were performed using a Neubauer chamber and stained smears by Rapid Instant Prov Stain Set (Newprov Laboratory Products; São José dos Pinhais, PR, Brazil), respectively. Leukograms of the groups of rats (saline and ATV $27 \mathrm{mg} / \mathrm{kg}$ ) were performed before alveolar bone loss induction, at 6th $\mathrm{h}$ and $2 \mathrm{nd}, 7$ th and 11 th day after the ligature.

\section{Serum Biochemical Parameters of Kidney and Liver Function}

At baseline and on the $11^{\text {th }}$ day, blood samples were collected from orbital plexus of anesthetized rats (saline and ATV $27 \mathrm{mg} / \mathrm{kg}$ ). Serum levels of urea and creatinine were evaluated as renal function markers, while serum levels of aspartate aminotransferase (AST) and alanine aminotransferase (ALT) were used as liver function markers. Specific kits were used and methodology followed the manufacturer's instructions (Labtest ${ }^{\circledR}$ ).

\section{Body Mass Variation}

Rats from groups SAL and ATV $27 \mathrm{mg} / \mathrm{kg}$ were weighted before $A B L$ induction and then daily until the $11^{\text {th }}$ day. 


\section{Statistical Analysis}

The data are presented as mean \pm standard error of the mean (SEM) or median (minimum-maximum), where appropriate. Univariate analysis of variance (ANOVA), followed by Bonferroni test, were used to compare means, and Kruskal-Wallis and Mann Whitney tests were used to compare medians. A $p$ value of $<0.05$ was considered as indicating significant differences. All measurements were made blind to the groups.
Histopathological analysis indicated intense alveolar bone and cementum resorption, associated to important infiltration of inflammatory cells $(p<0.05)$ on SAL group (Table 1; Fig. 1E), compared with normal periodontium (Table 1; Fig. 1D). Rats treated with ATV (27 mg/kg) showed a significant inflammatory infiltrate attenuation and preservation of alveolar bone, periodontal ligament and cementum (Table 1; Fig. 1F), compared to SAL.

The histometric study corroborated the morphometric

\section{Results}

Morphometric study demonstrated that ligature-induced $A B L$ caused intense bone resorption (Table 1; Fig. 1B) compared to the normal hemi-maxillae (Table 1; Fig. 1A). Rats from SAL group presented intense alveolar resorption, root exposure and furcation lesion (Fig. 1B). Despite the lowest dose of ATV $(0.3 \mathrm{mg} / \mathrm{kg})$ not protecting alveolar bone, when compared to $\mathrm{SAL}$ (Table 1), the highest dose of ATV showed the greatest bone protection. The treatment with ATV (3 and $27 \mathrm{mg} / \mathrm{kg}$ ) elicited significant dosedependent alveolar bone protection by $39 \%$ and 56\% (Table 1; Fig. 1C).
Table 1 Morphometric, histological and histomorphometric analysis of rat maxillae submitted to ligature-induced ABL.

\begin{tabular}{lccccc}
\hline Analysis & Normal & Saline & $\begin{array}{c}\mathrm{ATV} 0.3 \\
\mathrm{mg} / \mathrm{kg}\end{array}$ & $\begin{array}{c}\mathrm{ATV} 3 \\
\mathrm{mg} / \mathrm{kg}\end{array}$ & $\begin{array}{c}\mathrm{ATV} 27 \\
\mathrm{mg} / \mathrm{kg}\end{array}$ \\
\hline Macroscopic $\left(\mathrm{mm}^{2}\right)$ & - & $4.2 \pm 0.3$ & $4.2 \pm 0.3$ & $2.6 \pm 0.3^{*}, \#$ & $1.8 \pm 0.2^{*}, \#$ \\
Histometric $(\mathrm{mm})$ & $0.1 \pm 0.0^{*}$ & $0.4 \pm 0.0$ & - & - & $0.2 \pm 0.0^{*}$ \\
Histological (scores) & $0(0-0)^{*}$ & $3(2-3)$ & - & - & $1.5(0-2)^{*}$ \\
\hline
\end{tabular}

Macroscopic and Histometric data are expressed as mean \pm standard error of the mean (SEM) of alveolar bone loss of six animals, and Histological data are expressed as median and range of six animals. ${ }^{*} p<0.05$ indicates statistically significant difference when compared to Saline group. \#p<0.05 indicates statistically significant difference when compared to ATV $0.3 \mathrm{mg} / \mathrm{kg}$ (ANOVA and Bonferroni's test or Kruskal-Wallis and Dunn test when appropriated). ATV $=$ Atorvastatin.
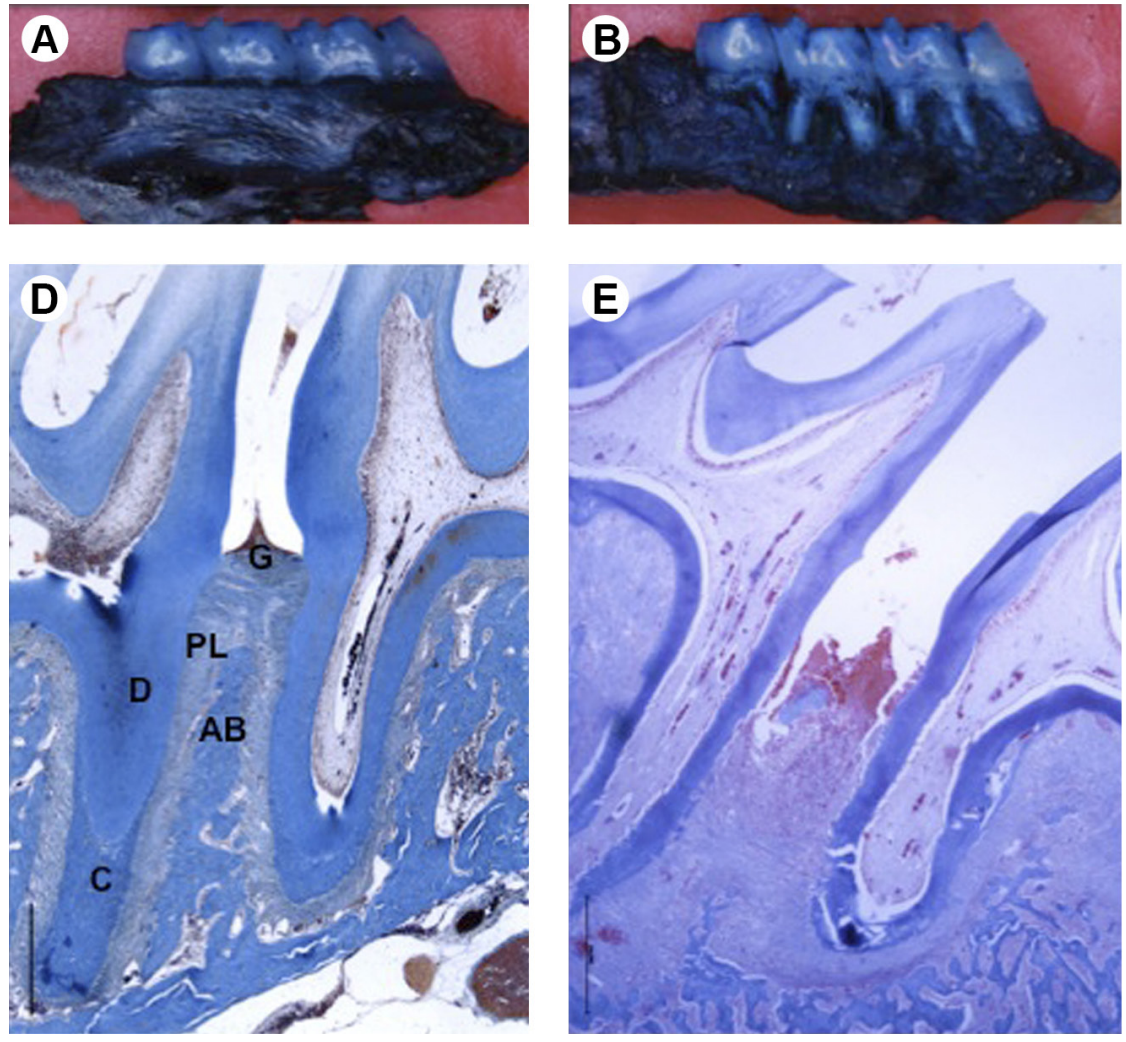
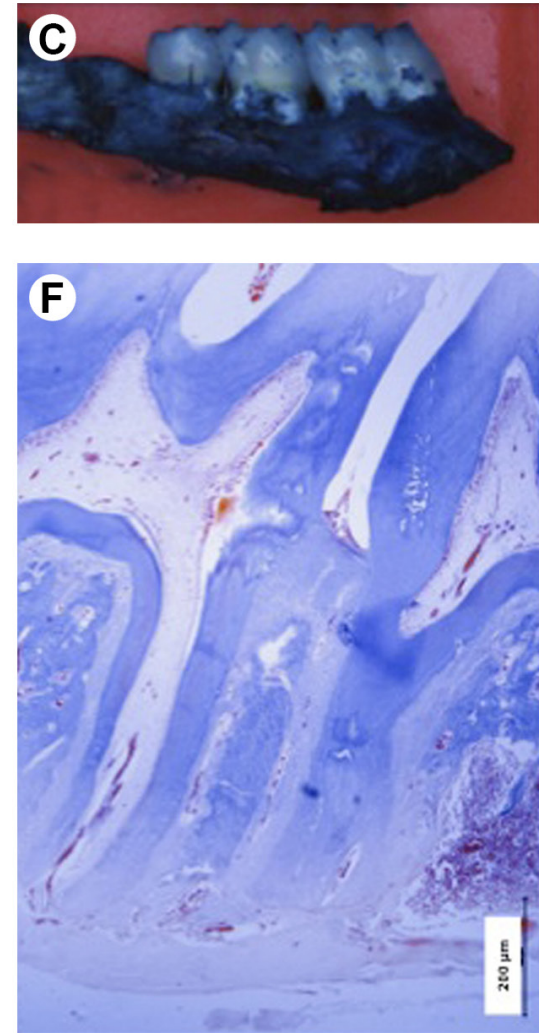

Figure 1. Macroscopic and microscopic aspects respectively of normal group (A and D) Saline group (B and E) and ATV $27 \mathrm{mg} / \mathrm{kg}$ group (C and F). $\mathrm{G}=$ gingival; $\mathrm{PL}=$ periodontal ligament; $\mathrm{AB}=$ alveolar bone; $\mathrm{D}=$ dentin; $\mathrm{C}=$ cementum. (Microscopic aspect: Mallory trichrome staining; original magnification 40x; Bar=200 $\mu \mathrm{m}$ ). 
and histological findings. It was seen that 11 days of ligature-induced $A B L$ caused intense bone resorption compared to normal periodontium $(p<0.05)$. Treatment with ATV $27 \mathrm{mg} / \mathrm{kg}$ prevented $A B L$ when compared to saline $(p<0.05)($ Table 1).

When BALP serum levels were evaluated, a significant decrease in SAL group was observed when compared to baseline. ATV prevented the reduction of BALP serum levels compared to SAL (Table 2).

In order to verify systemic repercussions after treatment with ATV, some parameters were evaluated. On leukogram, ligature-induced $A B L$ caused leukocytosis at 6 th $\mathrm{h}$ after ligature placement $\left(19.5 \pm 0.9\right.$ leukocytes $\left.\times 103 / \mathrm{mm}^{3}\right)$ (Fig. $2 A)$, compared to the baseline $\left(12.37 \pm 0.57 \times 103 / \mathrm{mm}^{3}\right)$. The leukocytosis observed at 6 th $\mathrm{h}$ was marked by neutrophilia $\left(6.8 \pm 0.9 \times 103 / \mathrm{mm}^{3}\right)$ (Fig. 2b). Following, a new leukocytosis was observed at the 11 th day $(18.2 \pm 1.2$ leukocytes $\times 103 /$ $\left.\mathrm{mm}^{3}\right)$ with prevalence of mononuclear cells $(15.8 \pm 0.6 \mathrm{x}$ $103 / \mathrm{mm}^{3}$ ) (Fig. 2c). ATV ( $27 \mathrm{mg} / \mathrm{kg}$ ) significantly reduced leukocytosis $\left(13.9 \pm 1.2\right.$ leukocytes $\left.\times 103 / \mathrm{mm}^{3}\right)$ (Fig. $\left.2 \mathrm{~A}\right)$ and neutrophil count at the 6 th $\mathrm{h}\left(4.4 \pm 0.4 \times 103 / \mathrm{mm}^{3}\right)$ (Fig. 2b). At the 11th day, ATV also significantly lowered mononuclear cell count $\left(12.1 \pm 1.3 \times 103 / \mathrm{mm}^{3}\right)$ (Fig. 2A).

Kidney (urea and creatinine) and liver (AST and ALT) enzymes were analyzed (Table 2). In the saline group an increase on creatinine serum levels was observed $(p<0.05)$ compared to baseline. ATV $(27 \mathrm{mg} / \mathrm{kg})$ prevented this increase. No change was seen in urea serum levels after ATV treatment. For liver transaminases, a significant increase was seen in ALT serum levels in the SAL group compared to baseline. ALT levels were increased $(p<0.05)$ in ATV group compared to saline or baseline. No modification was observed in AST serum levels after ATV treatment.

Table 2. Serum biochemical dosages of animals submitted to ligatureinduced periodontitis

\begin{tabular}{lccc}
\hline & \multicolumn{3}{c}{ Groups } \\
\cline { 2 - 4 } Dosages & Baseline & Saline & $\begin{array}{c}\text { ATV } \\
27 \mathrm{mg} / \mathrm{kg}\end{array}$ \\
\hline BALP (U/l) & $137.6 \pm 8.4$ & $83.0 \pm 8.4 \#$ & $116.3 \pm 5.1^{*}, \#$ \\
Urea (mg/dl) & $40.1 \pm 2.7$ & $39.6 \pm 2.6$ & $51.1 \pm 4.3$ \\
Creatinine (mg/dl) & $0.6 \pm 0.1$ & $1.4 \pm 0.0 \#$ & $0.4 \pm 0.1^{*}$ \\
AST (U/l) & $57.2 \pm 5.5$ & $64.3 \pm 2.4$ & $41.1 \pm 4.0$ \\
ALT (U/l) & $14.5 \pm 0.5$ & $38.7 \pm 2.8 \#$ & $49.9 \pm 5.7^{*}, \#$ \\
\hline
\end{tabular}

Data represent the mean \pm standard error of the mean (SEM) of each dosage of six animals, ${ }^{*} \mathrm{p}<0.05$ indicates statistically significant difference when compared to SAL group. \# $\mathrm{p}<0.05$ indicates statistically significant difference when compared to Baseline (ANOVA and Bonferroni's test). BALP = Bone-specific alkaline phosphatase; $\mathrm{AST}=$ Aspartate aminotransferase ALT = Alanine aminotransferase; ATV $=$ Atorvastatin .
Considering body mass variation, ligature-induced $A B L$ caused significant loss in body mass after ligature placement from 2nd until the 6th day, compared to normal animals. Animals treated with ATV did not show additional loss of body weight when compared to SAL (Fig. 3).

\section{Discussion}

This study demonstrated that ligature-induced $A B L$ caused significant bone resorption, periodontal
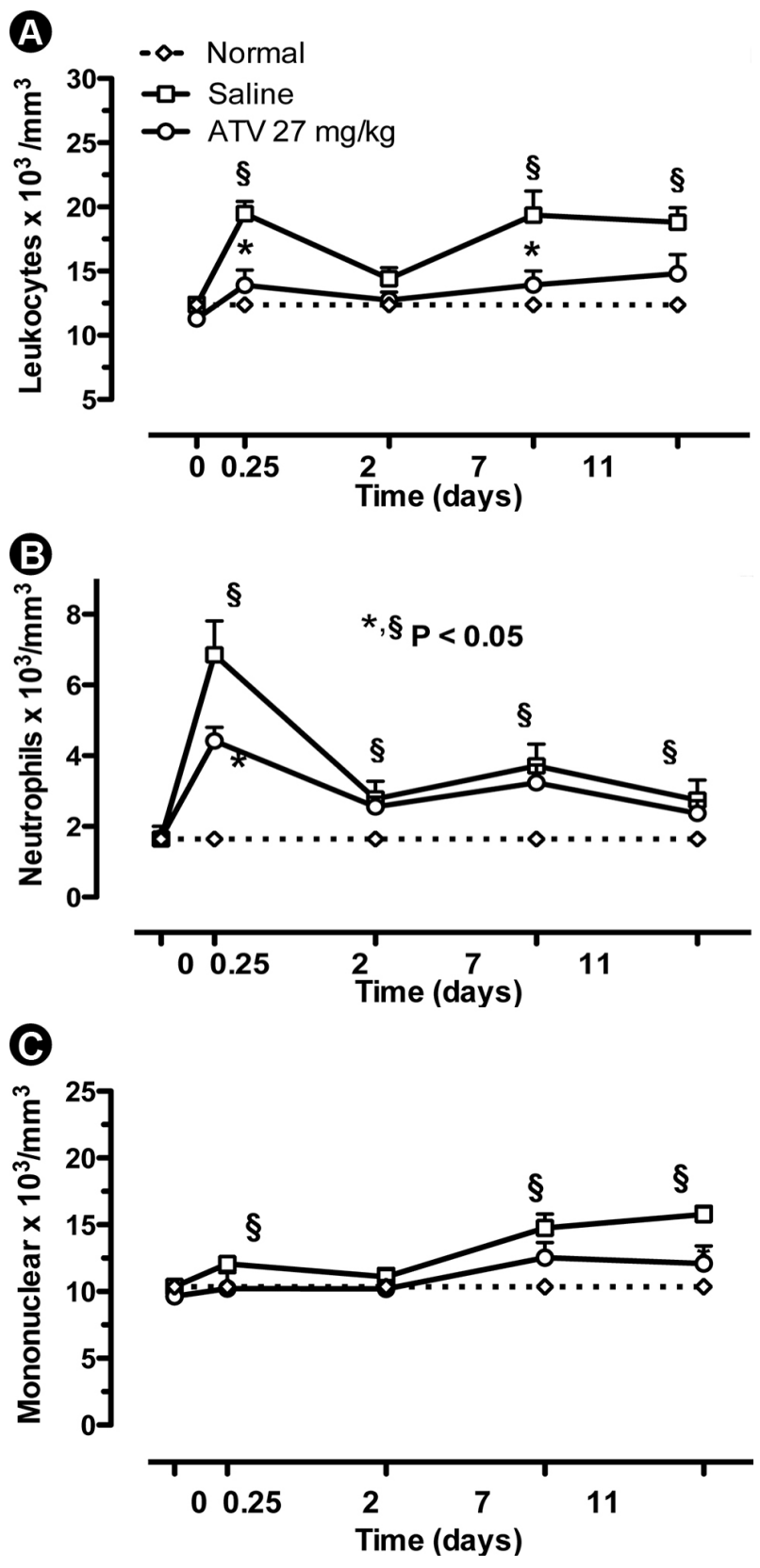

Figure 2. Effect of atorvastatin (ATV) on leukocyte counts. Each point represents the mean value \pm standard error of the mean (SEM) of total leukocytes (a), neutrophils (b), mononuclear cells (c) x 103/ $\mathrm{mm}^{3}$. ${ }^{*} \mathrm{p}<0.05$ indicates statistically significant difference when compared to saline group. $\$ p<0.05$ indicates statistically significant difference compared to baseline (ANOVA and Bonferroni test). 
inflammation and decrease on BALP serum levels as demonstrated previously (8). The treatment with ATV significantly prevented $A B L$ alveolar bone loss, which is in accordance with other authors (7). ATV also prevented inflammation as well as reduction of BALP serum levels.

As a hypolipemiant drug, ATV is also known to have pleiotropic effects. Beyond lipid lowering action, it has been reported that ATV is able to inhibit important inflammatory mediators such as interleukins (IL) -6 and -1 and tumor necrosis factor (TNF) (10). Since these cytokines are also involved in alveolar bone resorption (11), the antiinflammatory effect of ATV contributes to bone protection, as seen in this study.

In vitro studies have shown that ATV has anabolic bone properties. Statins may increase up to 50\% new bone formation and promote osteoblastic differentiation and mineralization (12). Regarding the alveolar bone, a clinical trial suggested that ATV might have beneficial effects on bone alveolar loss and tooth mobility in subjects with periodontal disease (13). Such bone anabolic property seems be related to the drug lipophilicity and this ATV chemical characteristic may elicit greater mineralization process (4).

Considering the effect of ATV on osteoblastic differentiation and mineralization, it was decided to evaluate BALP serum level, an isoenzyme of total alkaline phosphatase (TAP) considered a bone formation marker, due to its linkage with osteoblastic differentiation and mineralization of newly formed bone (14). Thus, BALP plays an important role in the regulation of bone formation and turnover rate. The results showed that ATV treatment prevented BALP reduction. Several studies have examined the relationship between statin use and biochemical markers of bone turnover. Clinical trials have supported this finding, reporting that ATV treatment does not modify

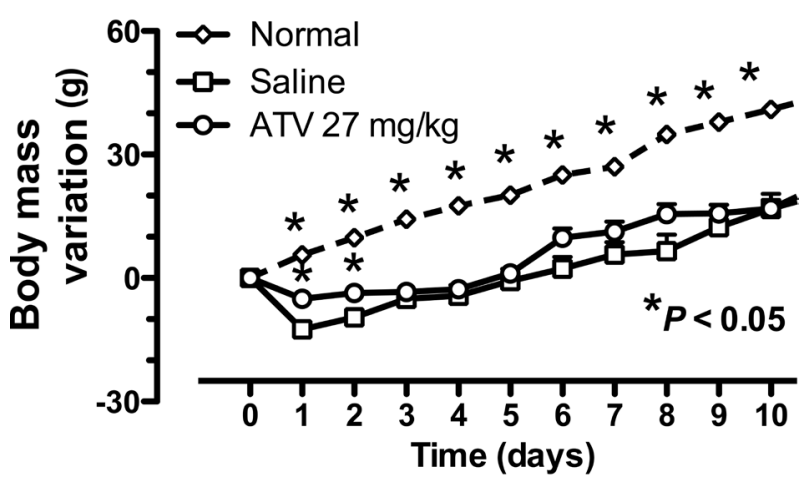

Figure 3. Effect of atorvastatin (ATV) on variation of corporal mass of rats. Animal body mass was measured daily for 11 days. Each point represents the mean \pm standard error of the mean (SEM) of body mass variation $(\mathrm{g})$ of at least six animals. ${ }^{*} \mathrm{p}<0.05$ indicates statistically significant difference when compared to saline group. (ANOVA and Bonferroni test). or promote small variations on BALP serum levels in hypercholesterolemic patients (15), actually contributing to bone homeostasis.

Regarding systemic parameters, this study revealed that ATV prevented neutrophilia and lymphomonocytosis. Considering the markers of kidney and liver function, ATV prevented creatinine raise, as seen in SAL group, but did not prevent ALT increase. However, no changes on AST serum levels were observed after therapy with ATV. ATVdid not alter body mass compared to SAL.

Considering the leukocyte counts, ATV prevented peripheral neutrophilia and lymphomonocytosis, as seen in saline group on 6th and 11th days, respectively. In agreement with the present data, studies have shown that ATV treatment caused significant reduction in peripheral leukocyte (16), preventing neutrophilia. Additionally, ATV has been described to reduce circulating classical monocytes in humans after heart transplantation (17).

As the ATV treatment significantly decreased creatinine serum levels, it could be assumed that this drug does not produce renal disturbances. In fact, several studies have reported that statin therapy does not induce tubular dysfunction (18) or alter glomerular filtration, even in higher doses (19) and that may afford protection of renal function in acute unilateral ureteral obstruction (20).

About liver biomarkers, it was seen that ATV did not alter AST serum levels, but promoted increase on ALT compared to baseline and saline group. It has been reported that all statins can induce asymptomatic mild elevation of serum transaminases with a quoted incidence between $1 \%$ and $1.5 \%$, but this rarely requires withdrawal of the drug (21). The elevation of serum transaminases is often self-limiting and thought to be related to alteration of the hepatocyte cellular membrane with enzyme leakage, rather than to direct liver injury (22). The risk of a significant increase in serum transaminases while using statins, especially ATV, is considered to be dose-dependent (22). In comparison to other statins, ATV is a significantly longer acting drug. It has been hypothesized that the longer exposure to ATV could explain an increased risk of hepatic toxicity compared to other statins (22). However, as ATV has a more pronounced activity in lowering serum low-density lipoprotein, this in turn could influence the structure of cellular membranes, leading to greater leakage of cellular enzymes and increased incidence of 'transaminitis' without direct hepatic toxicity (23).

About body mass variation, it was observed that the ligature-induced important weight loss in the first 2 days of experiment, due to the trauma during ligature placement, as seen in previous reports $(6,8)$. The treatment with ATV did not prevent the initial loss of weight presented similar body mass variation compared to saline, confirming that 
statin therapy does not interfere on body mass index (24), probably due to ATV being devoid of analgesic action (25).

In summary, this study showed an important protecting effect of ATV in ligature-induced periodontitis, without affecting systemic parameters. It can be suggested that in addition to its anti-inflammatory effect, ATV $(27 \mathrm{mg} / \mathrm{kg})$ protectively acted by its anabolic activity on the alveolar bone. Accordingly, the possibility of considering the ATV therapy as adjuvant treatment in human periodontitis deserves further investigation.

\section{Resumo}

0 objetivo do estudo foi avaliar o efeito anti-inflamatório e antireabsortivo da atorvastatina (ATV) no modelo de perda óssea alveolar experimental (POA). Para isto, ratos Wistar foram submetidos a inserção de ligadura ao redor do segundo molar maxilar durante 11 dias. Os animais receberam diariamente, por gavagem, soro fisiológico a 0,9\% (2 mg/kg) ou ATV $(0,3,3$ ou $27 \mathrm{mg} / \mathrm{kg}$ ). A POA foi avaliada pela área de reabsorção e análise histológica. Dosagens séricas da atividade de fosfatase alcalina óssea foram avaliadas. Leucograma foi realizado a $0 \mathrm{~h}$, na $6 \mathrm{a}$, $2^{\circ}, 7^{\circ}$ e $11^{\circ}$ dias. Foram analisadas condições de rim, fígado e variação de massa corpórea. As ATV (3 e $27 \mathrm{mg} / \mathrm{kg}$ ) inibiram POA em 39\% e 56\%, respectivamente. A análise histopatológica mostrou que a ATV $27 \mathrm{mg} / \mathrm{kg}$ preveniu POA e reabsorção de cemento, e o infiltrado celular inflamatório induzido por ligadura. ATV $(27 \mathrm{mg} / \mathrm{kg})$ preveniu a redução dos niveis séricos de fosfatase alcalina óssea. ATV $(27 \mathrm{mg} / \mathrm{kg}$ ) preveniu leucocitose e não afetou função renal e hepática ou o peso corporal. ATV mostrou um efeito protetor na periodontite induzida por ligadura, sem afetar os parâmetros sistêmicos, através da inibição do processo inflamatório e pela atividade anabólica no osso alveolar.

\section{Acknowledgements}

This work was supported by Ceará State Foundation for Technological and Scientific Development (FUNCAP) and National Counsel for Technological and Scientific Development (CNPq), Brazil.

\section{References}

1. Petersen $\mathrm{PE}$, Ogawa $\mathrm{H}$. Strengthening the prevention of periodontal disease: The WHO Approach. J Periodontol 2005;76:2187-2193.

2. Deo V, Bhongade ML. Pathogenesis of periodontitis: role of cytokines in host response. Dent Today 2010;29:60-62.

3. McLain K, Edlund BJ. Statin drugs: reducing cardiovascular risk in older adults. J Gerontol Nurs 2012;38:9-13.

4. Maeda T, Matsunuma A, Kurahashi I, Yanagawa T, Yoshida H, Horiuchi N. Induction of osteoblast differentiation indices by statins in MC3T3-E1 cells. J Cell Biochem 2004;92:458-471.

5. Horiuchi N, Maeda T. Statins and bone metabolism. Oral Disease 2006;12:85-101.

6. Lima V, Bezerra MM, Alencar VBM, Vidal FD, Rocha FA, Castro Brito GA, et al.. Effects of chlorpromazine on alveolar bone loss in experimental periodontal disease in rats. Eur J Oral Sci 2000;108:123-129.

7. Goes P, Lima AP, Melo IM, Rêgo ROCC, Lima V. Effect of atorvastatin in radiographic density on alveolar bone loss in Wistar rats. Braz Dent J 2010;21:193-198.
8. Goes P, Melo IM, Dutra CS, Lima AP, Lima V. Effect of alendronate on bone-specific alkaline phosphatase on periodontal bone loss in rats. Arch Oral Biol 2012;57:1537-1544.

9. Goes $P$, Melo IM, Silva LM, Benevides NM, Alencar NM, Ribeiro $R A$, et al.. Low-dose combination of alendronate and atorvastatin reduces ligature-induced alveolar bone loss in rats. J Periodontal Res. 2014;49:45-54

10. Zhang YY, Fan YC, Wang M, Wang D, Li XH. Atorvastatin attenuates the production of IL-1 $\beta, I L-6$, and TNF- $\alpha$ in the hippocampus of an amyloid $\beta 1-42$-induced rat model of Alzheimer's disease. Clin Interv Aging 2013;8:103-110

11. Fentoğlu 0 , Kirzioğlu FY, Ozdem $M$, Koçak $H$, Sütçü $R$, Sert T. Proinflammatory cytokine levels in hyperlipidemic patients with periodontitis after periodontal treatment. Oral Dis 2012;18:299-306.

12. Mundy G, Garrett R, Harris S, Chan J, Chen D, Rossini G, et al.. Stimulation of bone formation in vitro and in rodents by statins. Science 1999;286:1946-1949.

13. Fajardo ME, Rocha ML, Sánchez-Marin FJ, Espinosa-Chávez EJ. Effect of atorvastatin on chronic periodontitis: a randomized pilot study. J Clin Periodontol 2010;37:1016-1022.

14. Couttenye MM, D'Haese PC, Van Hoof VO, Lemoniatou E, Goodman $W$, Verpooten GA, et al.. Low serum levels of alkaline phosphatase of bone origin: a good marker of adynamic bone disease in haemodialysis patients. Nephrol Dial Transplant 1996;11:1065-1072.

15. Majima T, Komatsu Y, Fukao A, Ninomiya K, Matsumura T, Nakao K. Short-term effects of atorvastatin on bone turnover in male patients with hypercholesterolemia. Endocrine J 2007;54:145-151.

16. Medeiros CA, Leitão RF, Macedo RN, Barboza DR, Gomes AS, Nogueira $N A$, et al.. Effect of atorvastatin on 5-fluorouracil-induced experimental oral mucositis. Cancer Chemother Pharmacol 2011;67:1085-1100.

17. Fildes JE, Shaw SM, Mitsidou A, Rogacev K, Leonard CT, Williams SG, et al.. HMG-CoA reductase inhibitors deplete circulating classical and non-classical monocytes following human heart transplantation. Transpl Immunol 2008;19:152-157.

18. Paulsen L, Holm C, Bech JN, Starklint J, Pedersen EB. Effects of statins on renal sodium and water handling. Nephrol Dial Transplant 2007;0:16.

19. Paulsen L, Matthesen SK, Bech JN, Starklint J, Pedersen EB. Acute effects of atorvastatin on glomerular filtration rate, tubular function, blood pressure, and vasoactive hormones in patients with type 2 diabetes. J Clin Pharmacol 2010;50:816-822.

20. Kamdar C, Chou SY, Mooppan UM, Kim H, Gulmi FA. Atorvastatin protects renal function in the rat with acute unilateral ureteral obstruction. Urology 2010;75:853-857.

21. Bolego C, Baetta R, Bellosta S, Corsini A, Paoletti R. Safety considerations for statins. Curr Opin Lipidol 2002;13:637-644.

22. Calderon RM, Cubeddu LX, Goldberg RB, Schiff ER. Statins in the treatment of dyslipidemia in the presence of elevated liver aminotransferase levels: a therapeutic dilemma. Mayo Clin Proc 2010;85:349-356.

23. Dujovne CA. Side effects of statins: hepatitis versus "transaminitis"myositis versus "CPKitis". Am J Cardiol 2002;89:1411-1413.

24. Georgescu EF, Georgescu M. Therapeutic options in non-alcoholic steatohepatitis (NASH). Are all agents alike? Results of a preliminary study. J Gastrointestin Liver Dis 2007;16:39-64.

25. Jaiswal SR, Sontakke SD. Experimental evaluation of analgesic and anti-inflammatory activity of simvastatin and atorvastatin. Indian J Pharmacol 2012;44:475-479. 